This study was undertaken to investigate the correlation between the serum ECP and the serum eotaxin level, and disease activity as evaluated with pulmonary function in patients with asthma or chronic obstructive pulmonary disease (COPD). 20 patients with stable asth $m$ and 15 patients with COPD, and 15 subjects of the control group took part in this study. The analysis of ECP was performed according to the manufacturer's directions (Pharmacia Diagnostics AB, Uppsala, Sweden). The ELISA test was used to measure eotaxin levels in sserum (kits from $R \& D$, USA). The levels of ECP were $16.9 \pm 6.3 \mu \mathrm{g} / \mathrm{L}$ in patien ts with asth $\mathrm{ma}, 15.1 \pm 9.3 \mu \mathrm{g} / \mathrm{L}$ in patients with COPD and $11.8 \pm 6.2 \mu \mathrm{g} / \mathrm{L}$ in the control group $(P<0.05)$. There was no significant difference in the asthma ECP level compared with the ECP level in COPD. There was a significant difference between the ECP plasma level in asth ma compared with the ECP plasma level in the control group $(p<0.05)$. The levels of eotaxin were $175.8 \pm 49.3 \mathrm{pg} / \mathrm{mL}$ in the control group. There was a correlation of ECP and the eotaxin level in asthma patients $(r=+0.5, p<0.05)$. The percentage fall in FEV1 correlated with eotaxin level in asthma $(r=-0.3$, $p<0.05)$ and with the eotaxin level in COPD $(r=-0.5$, $p<0.05)$. Serum outcomes of eotaxin and ECP levels appear to be a useful indicator of atopic asth $m a$, and might provide complementary data disease monitoring. Therefore, further investigations are required to clarify whether serum eotaxin measurements have a role in the clinical evaluation in COPD.

Key words: Eotaxin, Eosinophil cationic protein, Asthma, COPD

\section{Eotaxin in serum of patients with asthma or chronic obstructive pulmonary disease: relationship with eosinophil cationic protein and lung function}

\author{
Karina Jahnz-Różyk ${ }^{\mathrm{CA}}$, Tadeusz Plusa and \\ Justyna Mierzejewska
}

Departments of Internal Medicine, Pneumonology and Allergology, Central Clinical Hospital, Military School of Medicine, 128 Szaserów St., Warsaw 00-909, Poland

\footnotetext{
${ }^{\mathrm{CA}}$ Corresponding Author

e-mail:krozyk@poczta.onet.pl
}

\section{Introduction}

Asthma and chronic obstructive pulmonary diseases are a complex of conditions, which have airflow limitation in common. ${ }^{1}$ The most characteristic features of asthma are short-term changes in the airway caliber, reversible airflow limitation, bronchial hyperresponsiveness as well as eosinophilic and lymphocytic airway inflammation. The common definition of COPD implies long-term changes in airway caliber, less or irreversible airflow obstruction, seldom or no bronchial hyperresponsiveness and neutrophilic airway inflammation. Some studies have suggested a pathogenic role for airway inflammation in inducing hypersecretion of mucus, lung destruction and airway obstruction.

Eosinophils are believed to be critical proinflammatory cells in airways mucosal damage in asthma by releasing highly toxic proteins. One of these proteins, eosinophil cationic protein (ECP), can be quantitated in bronchial secretion and peripheral blood. Serum ECP levels have been found to be correlated with the severity of asthma, ${ }^{2}$ exercise- induced bronchoconstriction ${ }^{3}$ and allergen exposure. ${ }^{4}$ It has been found that ECP can be used to monitor asthma inflammation ${ }^{5}$ and may be a useful marker in selecting allergic patients with eosinophil related activation to allergen exposure. ${ }^{6}$ Setta et al. however, found that the numbers of tissue eosinophils are markedly and significantly increased when there is an exacerbation of bronchitis, and that associated with the exacerbation their numbers are similar to those reported in stable asthma. ${ }^{7}$ An increased level of ECP was observed in the sputum and bronchial lavage from patients with COPD. ${ }^{8,9}$

Several chemokines of the CC family, including eotaxin, RANTES, monocyte chemotactic protein 3 (MCP-3) and MCP-4 have been shown to attract and activate eosinophils via high affinity binding to CCR $3 .{ }^{10,11}$ However, only eotaxin binds selectively to this receptor, which supposedly explains why eotaxin is relatively selective in eosinophil recruitment. ${ }^{12}$

The CC chemokine eotaxin is a potent and selective chemoattractant, which signals via the CCR3 receptor. It has been found to be a potent chemoattractant for human eosinophils and basophils as well as a 
Table 1. FEVI (\% predicted, mean \pm SD)

\begin{tabular}{lcc}
\hline & FEV1 before salbutamol & FEV1 after salbutamol \\
\hline Asthma $(n=20)$ & $67.9 \pm 6.3(57-80)$ & $90.2 \pm 6.6(55-70)$ \\
COPD $(n=15)$ & $63.9 \pm 5.1(55-70)$ & $68.9 \pm 3.6(62-75)$ \\
Normal controls $(n=15)$ & $90 \pm 6.3(78-100)$ & Not done \\
Statistical significance & Asthma vs. COPD, $p=0.05$ & Asthma vs. COPD, $p<0.0001$ \\
& Asthma vs. control, $p<0.0001$ & \\
& COPD vs. control, $p<0.0001$ & \\
\hline
\end{tabular}

stimulator of oxygen radical production, $\mathrm{Ca}^{2+}$ mobilization, actin reorganization, and $\mathrm{CD} 11 \mathrm{~b}$ up-regulation for human eosinophils. ${ }^{13,14}$ The human eotaxin receptor, CCR3, is expressed on eosinophils, basophils, and TH2 cells. ${ }^{15}$ Eotaxin, in association with TH1-derived cytokine IL-2 and TH2-derived cytokine IL- 4 , is an important $\mathrm{T}$ lymphocyte activator, stimulating the directional migration, adhesion, accumulation, and recruitment of $\mathrm{T}$ lymphocytes, in parallel with the accumulation of eosinophils and basophils during the process of certain types of inflammation such as allergy. The synergism between remotely acting IL-5 and locally acting eotaxin will induce a rapid recruitment of eosinophils in the allergen-stimulated tissue. ${ }^{16}$ To our knowledge, there is no known role of this chemokine in the pathomechanism of asthma and COPD.

The aim of this study was to investigate the correlation between the serum ECP, serum eotaxin level and disease activity as evaluated with pulmonary function in patients with asthma or COPD.

\section{Material and methods}

20 patients (11 women and 9 men; mean age $27.7 \pm$ 4.8) with asthma, 15 (6 women and 11 men, mean age $60.9 \pm 8.1$ ) with COPD and 15 subjects ( 8 women and 7 men, mean age $36.8 \pm 10.5$ ) from the control group took part in this study.

The patients with asthma showed the following characteristics: one or more positive skin weal-andflare response to skin prick testing with a range of local allergens, history indicating several episodes of bronchoconstriction over a period of at least 2 years, and in relation to the exposure to one or more of those allergens, reversible airflow obstruction with a $>20 \%$ increase in the forced expiratory volume $1 \mathrm{~s}$ (FEV1) after inhaled $\beta 2$-receptor agonists $(400 \mu \mathrm{g}$ salbutamol) and airway hyperresponsiveness, as demonstrated by a cumulative histamine provocation dose causing a $100 \%$ increase in expiratory resistance (PD100Raw) on more than one occasion during the previous 30 days. None of the tested patients was a current smoker. They were stable at the time of testing, requiring only intermittent use of short-acting $\beta 2$ receptor agonists. The subjects with COPD had not been hospitalized for the exacerbation of the illness and met the following criteria: chronic sputum production, cough, low FEV1/VC ratio, increase in FEV1 following inhaled $\beta 2$-agonist of $<12 \%$, no history of seasonal or episodic dyspnea, wheezing or atopy, current cigarette smoking without occupational or other exposure known to cause chronic bronchitis, and no therapy with oral or inhaled glucocorticosteroids within 3 months of entry into the study. All of the control subjects were lifelong nonsmokers, with normal spirometry and with no history of atopy.

Each study subject had pulmonary function studies including vital capacity, forced expiratory volume in $1 \mathrm{~s}$ (FEV1), forced expiratory flow at 50\% (FEF50) and expiratory resistance (Raw). Spirometry was performed with Pneumoscreen equipment between 08:00 and 09:00 am.

Blood drawing, handling and storage were performed by the same researcher in the same department. No significant variation in temperature was observed between the room where blood was drawn and the laboratory where the preparation and storage of the serum took place. The blood samples were centrifuged at $1300 \times g$ at $4^{\circ} \mathrm{C}$ for $10 \mathrm{~min}$, stored at $-70^{\circ} \mathrm{C}$ until measurements of the ECP and eotaxin were taken. The analysis of ECP was performed according to the manufacturer's directions (Pharmacia Diagnostics AB, Uppsala, Sweden). The detection limit of this kit is $2.0 \mu \mathrm{g} / \mathrm{L}$. The analysis was performed blindly and each sample measurement was performed in duplicate.

An ELISA system sensitive enough to detect $5 \mathrm{pg} / \mathrm{ml}$ of human eotaxin was used to determine eotaxin serum level (kits from R\&D, USA). The variation in the measured eotaxin levels was always less than 3\% when samples were analyzed in duplicate on an ELISA plate.

The study was approved by the ethics committee of our hospital, and written informed consent was obtained from all participating subjects.

\section{Statistical analysis}

Statistical analysis of the data was performed by the SPSS Window 5.0 statistics program. Results were 


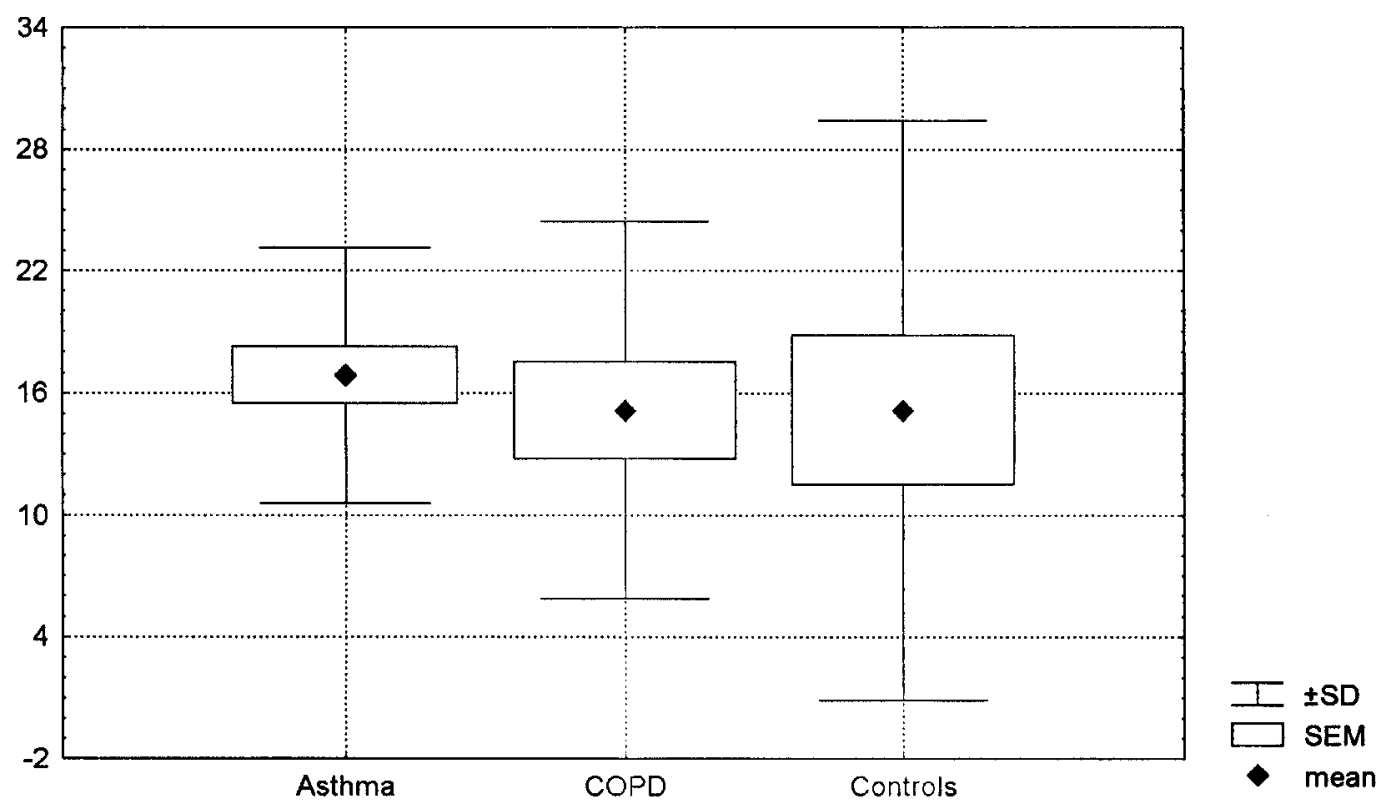

FIG. 1. Serum ECP $(\mu \mathrm{g} / \mathrm{L})$ in asthma, COPD, and controls.

expressed as mean $\pm \mathrm{SD}$. Correlations among variables were determined with an analysis to give the Pearson's rank correlation coefficient. A $p$ value of less than 0.05 was considered significant.

\section{Results}

The mean levels of expired volumes after $1 \mathrm{~s}$ (FEV1) are shown in Table 1. FEV1 was significantly reduced in patients with asthma and COPD compared to the control group $(p<0.05)$. All of the patients studied had detectable levels of plasma ECP and eotaxin.
The levels of ECP were $16.9 \pm 6.3 \mu \mathrm{g} / \mathrm{L}$ in patients with asthma, $15.1 \pm 9.3 \mu \mathrm{g} / \mathrm{L}$ in patients with $\mathrm{COPD}$ and $11.8 \pm 6.2 \mu \mathrm{g} / \mathrm{L}$ in the control group $(p<0.05$ ) (Fig. 1). There was no significant difference in the asthma ECP level compared with the ECP level in COPD. There was a significant difference between the ECP plasma level in asthma compared to the ECP plasma level in the control group $(p<0.05)$.

The levels of eotaxin were $175.8 \pm 49.3 \mathrm{pg} / \mathrm{mL}$ in asthma patients, $286.0 \pm 101.4 \mathrm{pg} / \mathrm{mL}$ in COPD patients and $109.6 \pm 56.1 \mathrm{pg} / \mathrm{mL}$ in the control group (Fig. 2). There were significant differences in the asthma eotaxin level as compared to COPD

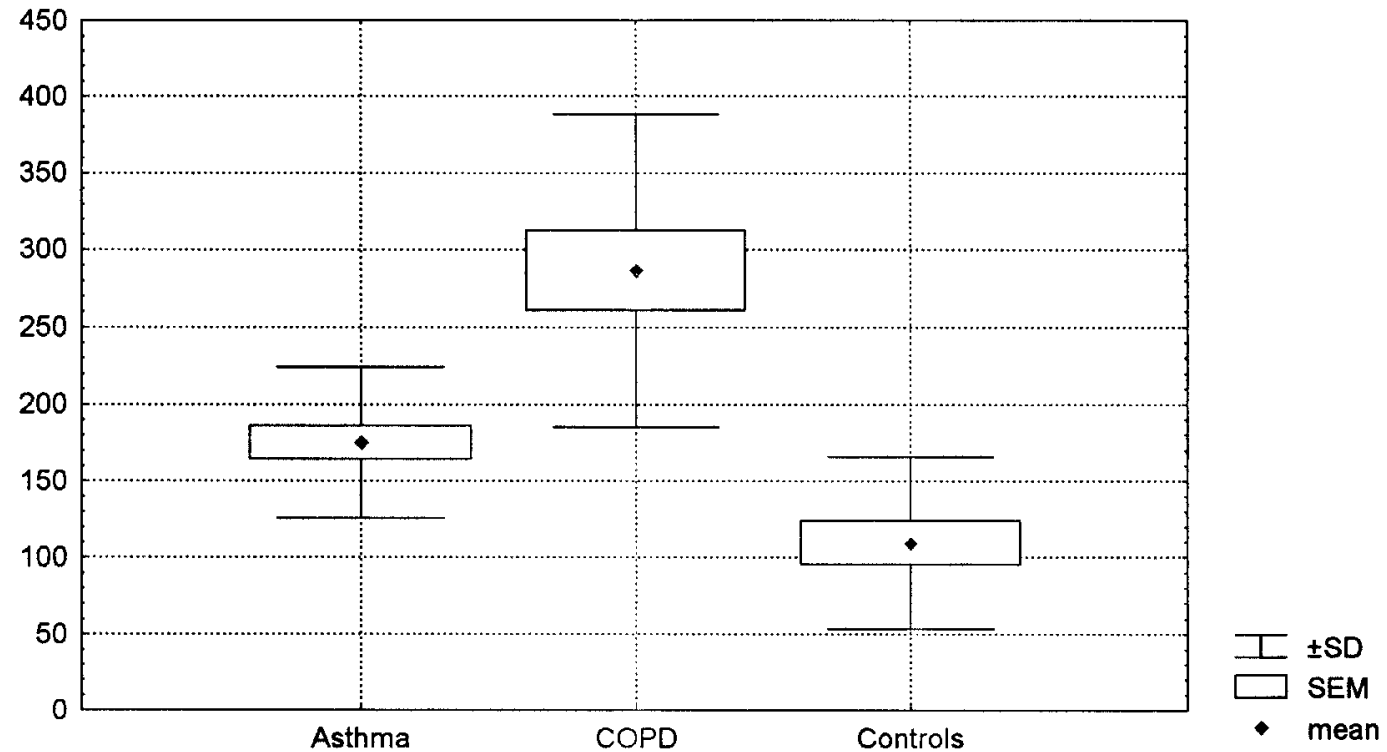

FIG. 2. Serum eotaxin $(\mathrm{pg} / \mathrm{mL})$ in asthma, COPD and controls. 


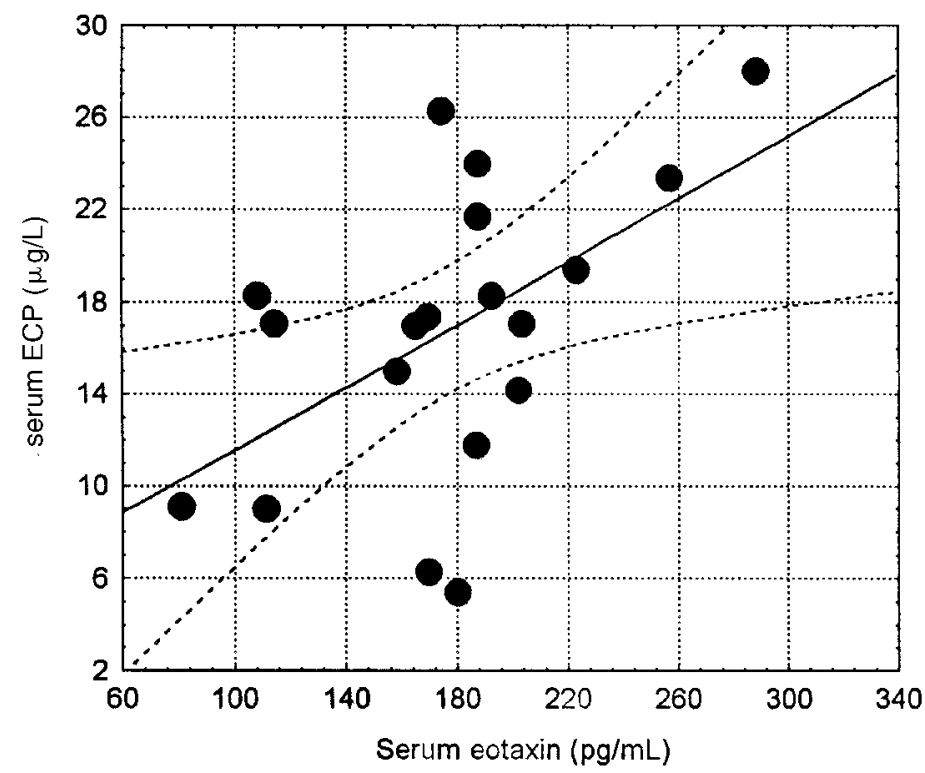

C Regression 95\%confidence 1eve 1

FIG. 3. Relationship between ECP and eotaxin levels in asthma patients. Corr. coeff. $=+0.5$.

$(p<0.0001)$, asthma as compared to the control group $(p<0.0001)$, and COPD as compared to the control group $(p<0.0001)$.

There was correlation of the ECP and the eotaxin level in asthma patients $(r=+0.5, p<0.05)$ (Fig. 3). The percentage fall in FEV1 correlated with the eotaxin level in asthma $(r=-0.3, p<0.05)$. There was correlation of the percentage fall in FEV1 with the eotaxin level in COPD $(r=-0.5, p<0.05)$.

\section{Discussion}

To our knowledge, this is the first time that an increase of eotaxin and ECP levels in serum of patients with asthma and COPD as well has been demonstrated. The study documented that serum eotaxin levels were significantly higher in COPD patients than in asthma patients and control subjects. Morever, the current investigation has shown that serum eotaxin levels are inversely related to the lung function (FEV1) in patients with asthma or COPD. However, only in asthma patients was significant correlation between ECP and eotaxin levels found.

The ELISA test is an accurate and useful method for quantifying human eotaxin in the blood, but the process of preparing blood samples affects the measurement of eotaxin levels. ${ }^{17}$ The previous study (Ref. 17) demonstrated that eotaxin levels in serum samples were significantly higher than those in matched plasma samples separated from the blood collected in tubes containing EDTA.

Since the serum measurement of ECP is relatively easy to perform and non-invasive, the usefulness of serum ECP as a clinical marker in asthma has recently been studied. ${ }^{6,18}$ The serum ECP level has been shown to be correlated with all the indices of eosinophilic inflammation or asthma activity, suggesting that serum ECP might be a very useful marker in the disease. ${ }^{18}$ In asthmatic patients, the serum ECP level demonstrated correlation with the number or percentage of eosinophils in BALF, and tissue, whereas the blood eosinophil count correlated only with the percentage of eosinophils in BALF. Our study showed that the serum level of ECP correlated with the elevated serum level of eotaxin. Elevated levels of eotaxin protein and mRNA have been demonstrated in the airways of asthmatic patients at baseline ${ }^{19}$ and after allergen inhalation. ${ }^{20}$ Moreover, eotaxin level and eosinophils increased at the onset of a viral respiratory infection in guinea pig bronchoalveolar lavage. ${ }^{21}$ Lilly et a $l$. found higher plasma eotaxin levels in patients with acute asthma. ${ }^{22}$ Acutely ill asthmatic subjects who did not respond to an emergency treatment had higher eotaxin levels than did those admitted to hospital or those discharged home. To our knowledge no studies have been conducted to investigate serum eotaxin levels in COPD patients. No study has also been performed on the correlation between the serum ECP level and the serum eotaxin level in COPD. Interestingly, the increase of eosinophils in the exacerbation of bronchitis is reported not to be accompanied by increases in the number of inflammatory cells showing immunoreactivity for IL-5 protein. ${ }^{23}$ Zhu et al. (unpublished) have, however, recently found that airways resected from smokers' lungs do demonstrate marked gene expression for IL-4 and IL-5, and that is, in particular, associated with the bronchial glands of subjects with chronic hypersecretion. The observation of the occurrence of both IL- 4 and IL-5 gene expression in COPD, questions further the distinctions between asthma and COPD and presents us with a new challenge for further 
research. In conclusion, we found a significantly higher serum eotaxin level in patients with COPD compared to patients with asthma. However, the outcomes of serum eotaxin and ECP levels appear to be a useful indicator of atopic asthma, and might provide complementary data in disease monitoring. Further longitudinal investigations should establish the role of measuring serum eotaxin in the clinical evaluation and monitoring of asthma, in particular, of COPD patients.

\section{References}

1. Jeffery PK. Differences and similarities between chronic obstructive pulmonary disease and asthma. Clin Exp Allergy 1999; 29:14-26.

2. Griffin E, Hakansson B, Formgren H, Jorgensen K, Peterson C, Venge P. Blood eosinophil number and activity in relation to lung function in patients with asthma and eosinophilia. J Allerg Clin Immunol 1991; 88:548-57.

3. Venge P, Henriksen J, Dahl R. Eosinophils in exercise induced asthma. J Allergy Clin Im munol 1991; 88:699-704.

4. Bonner A L, Peroni DG, Piacentini G, Venge P. Antigen avoidance in a mountain environment. III. Influence on serum markers of eosinophil activation in children with allergic asthma. J Allergy Clin Immunol 1993; 92:644-50.

5. Venge P. Serum measurements of eosinophilic cationic protein (ECP) in bronchial asthma. Clin Exp Allergy 1993; 23 (suppl. 2):3-7.

6. De Blay F, Purohit A, Stenger R, Gries P, Hamberger C, David B, Frossard N, Pauli G. Serum eosinophil cationic protein measurements in the management of perennial and periodic asthma: a prospective study. Eur Respir J 1998; 11:594-8.

7. Saetta M, Di Stefano A, Maestrelli P, Turato G, Ruggieri MP, Roggeri A, Calcagni P, Mapp CE. Airway eosinophilia in chronic bronchitis during exacerbation. Am J Respir Dis Crit Care Med 1994; 150:1646-52.

8. Fujimoto K, Kubo K, Yamamoto H, Yamaguchi S, Matsuzawa Y Eosinophilic inflammation in the airway is related to glucocorticoid reversibility in patients with pulmonary emphysema. Chest 1999; 115(3):697-702.

9. Pesci A, Balbi B, Majori M, Cacciani G, Bertacco S, Alciato P, Donner CF Inflammatory cells and mediators in bronchial lavage of patients with chronic obstructive pulmonary disease. Eur Respir J 1998; 12(2):380-6.

10. Gonzalo JA, Lloyd CM, Wen D, Albar JP, Wells TNC, Proudfoot A, Martinez C, Dorf M, Bjerke T, Coyle AJ, Gutierrez-Ramos JC. The coordinated action of CC chemokines in the lung orchestrates allertgic inflammation and airway hyperresponsivenes. J Exp Med 1998; 1:157-67.

11. Luster AD, Rothenberg ME. Role of the monocyte chemoattractant protein and eotaxin subfamily of chemokines in allergic inflammation. Leukoc Biol 1997; 62: 620-33.
12. White JR, Imburgia CH, Dul E, Appelbaum E, O'Donnel K, O'Shannessy DJ, Brawner M, Fornwald J, Adamou J, Elshourbagy NA, Kaiser K, Foley JJ, Schmidt DB, Johansson K, Macphee C, Morres K, McNulty D, Scott GF, Schleimer RP, Sarau HM. Cloning and functional characterization of a novel human CC chemokine that binds to the CCR3 receptor and activates human eosinophils. J Leukoc Biol 1997; 62:667-75.

13. Jose PJ, Griffiths-Johnson AD, Collins PD, Walsh DT, Moqbel R, Totty NF, Troung O, Hsuan J, Williams TJ. Eotaxin: a potent eosinophil chemoattractant cytokine detected in a guinea pig model of allergic airways inflammation. J Exp Med 1994; 179:881-7.

14. Yamada H, Hirai K, Miyamasu M, Ikura M, Misaki Y, Shoyi S, Takaishi T, Kasahara T, Morita Y, Ito K. Eotaxin is a potent chemotaxin for human basophils. Biochem Biophys Res 1997; 231:365-74.

15. Jinquan T, Quan S, Feili G, Larsen CHG, Thestrup-Pedersen K. Eotaxin activates Tcells to chemotaxis and adhesion only if induced to express CCR3 by IL-2 with IL-4. J Im munol 1999; 162:4285-92.

16. Collins PD, Marleau S, Griffiths-Johnson DA, Jose PJ, Williams TJ. Cooperation between interleukin-5 and the chemokine eotaxin to induce eosinophil accumulation in vivo. I Exp Med 1995; 182:1169-74.

17. Morita A, Shimosako K, Kikuoka S, Taniguchi Y, Kitaura M, Sasakura K, Tamaki M, Tsuji T, Teraoka H, Yoshie O, Nakajima T, Hirai K. Development of a sensitive enzyme-linked immunosorbent assay for eotaxin and measurement of its levels in human blood. J Im m unol Methods 1999; 226 (1-2):159-67.

18. Nimi A, Amitani R, Suzuki K, Tanaka T, Murayama T, Kuze F. Serum eosinophil cationic protein as a marker of eosinophilic inflammation in asthma. Clin Exp Allergy 1998; 28:233-40.

19. Lamkhioued B, Renzi PM, Abi Younes S, Garcia-Zepada EA, Allakholerdi Z, Ghaffar O, Rothenberg MD, Luster AD, Hamid Q. Increased expression of eotaxin in bronchoalveolar lavage and airways of asthmatics contributes to the chemotaxis of eosinophils to the site of inflammation. JIm m unol 1997; 159: 4593-601.

20. Zibecoglou K, Macfarlane AJ, Ying S, Meng Q, Pavord In Barnes NC, Robinson DS, Kay AB. Increases in eotaxin-positive cells in induced sputum from atopic asthmatic subjects after inhalational allergen challenge. Allergy 1999; 54:730-5.

21. Scheerens J, Folkerts G, Van der Linde P, Sterk J, Conroy DM, Williams TJ, Nijkamp FP. Eotaxin levels and eosinophils in guinea pig bronchoalveolar lavage fluid are increased at the onset of a viral respiratory infection. Clin Exp Allergy 1999; 29:74-77.

22. Lilly CM, Woodruff PG, Camargo CA, Camarg CA, Nakamura H, Drazen JM, Nadel ES, Hanrahan JP. Elevated plasma eotaxin levels in patients with acute asthma. J Allergy Clin Im munol 1999; 104:786-90.

23. Saetta M, Di Stefano A, Maestrelli P, Torato G, Mapp CE, Piono M. Zangauchio G, Del-Prete G, Fabri LM. Airway eosinophilia and expression of interleukin-5 protein in asthma and in the exacerbations of chronic bronchitis. Clin Exp Allergy 1996; 26:766-74.

Accepted after revision 30 August 2000 


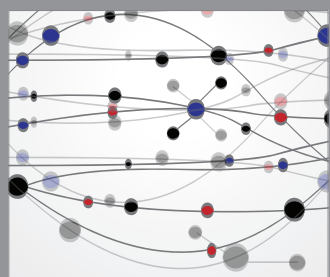

The Scientific World Journal
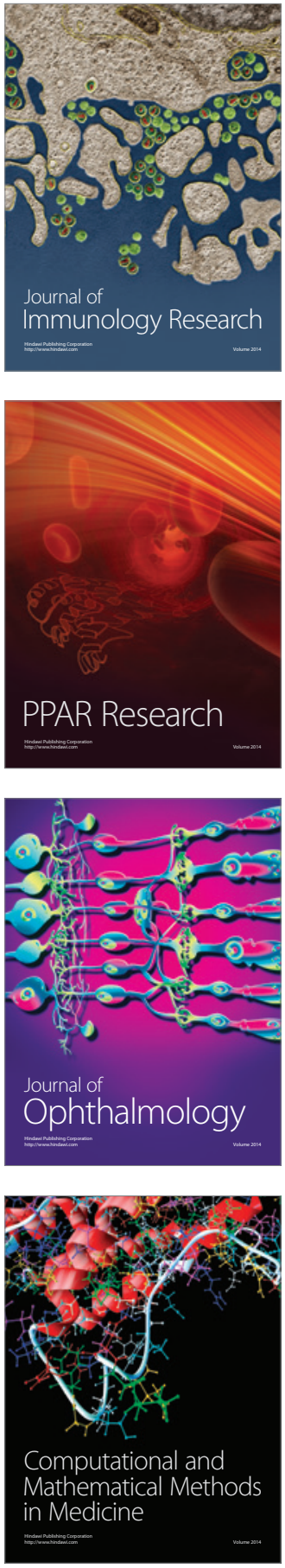

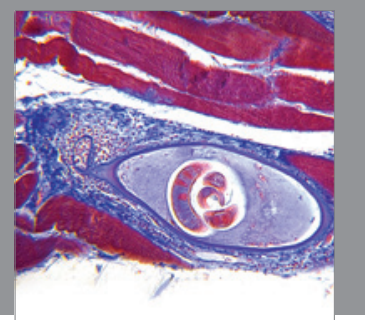

Gastroenterology

Research and Practice
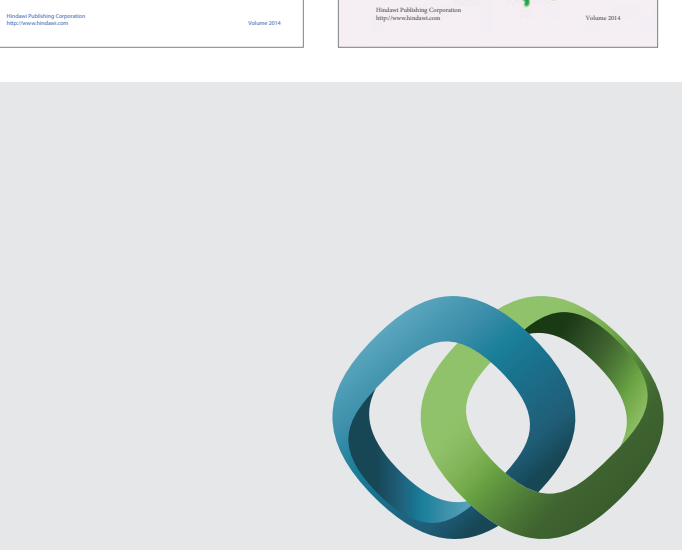

\section{Hindawi}

Submit your manuscripts at

http://www.hindawi.com
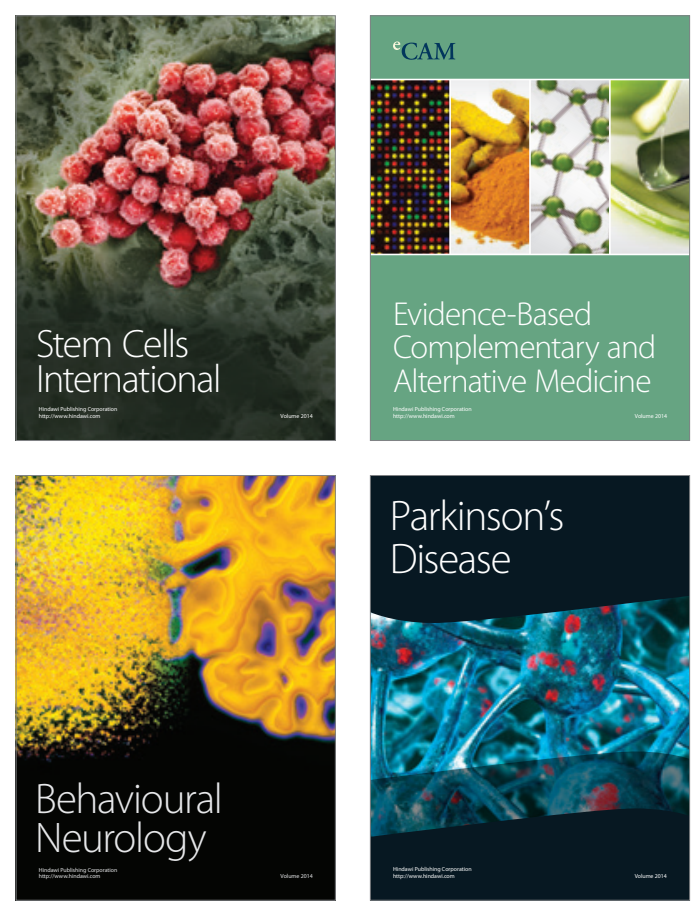

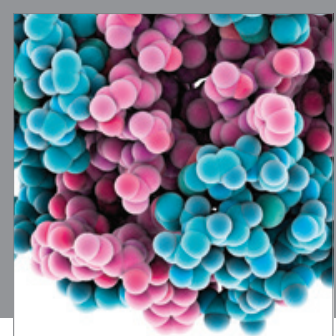

Journal of
Diabetes Research

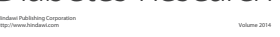

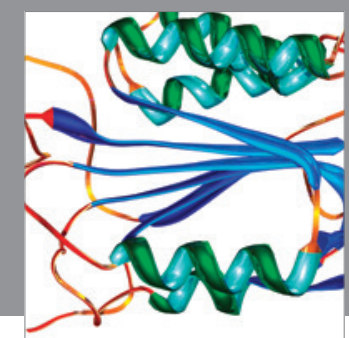

Disease Markers
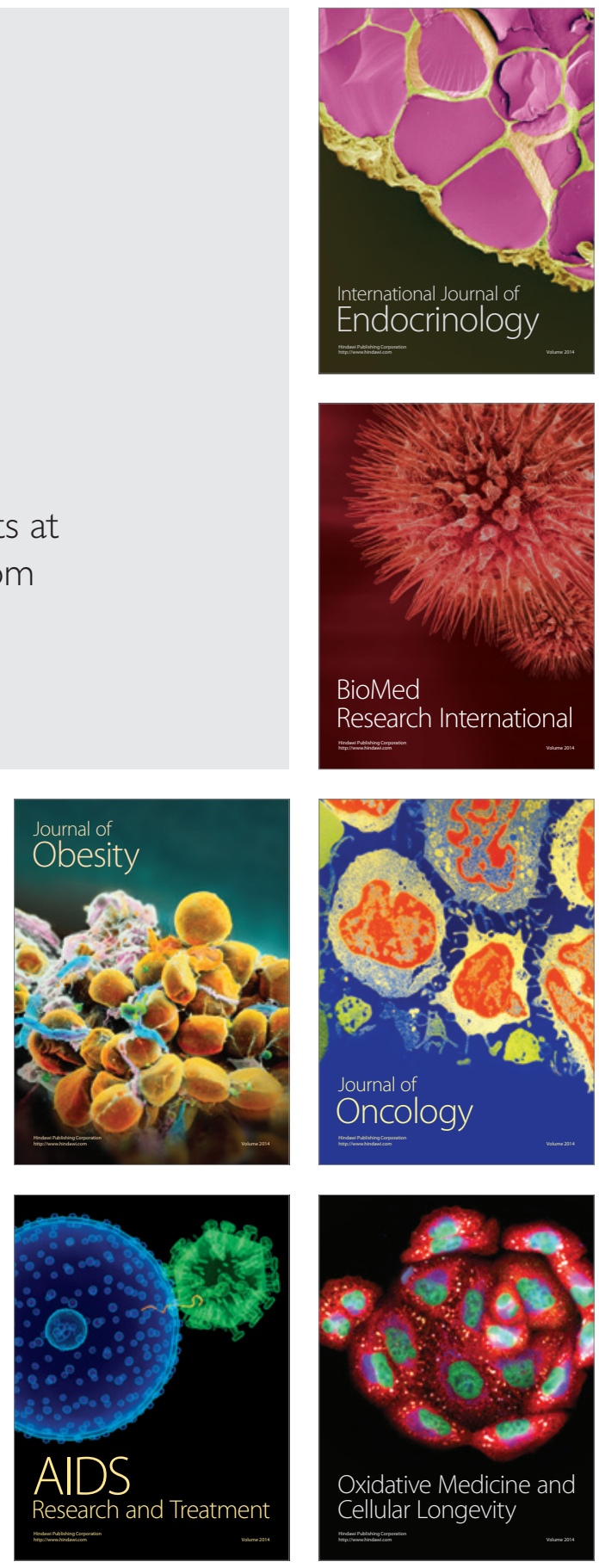